EUROPA REGIONUM TOM XXIII ROK 2015

DOI: $10.18276 /$ er.2015.23-29

JAROSŁAW LICHACY

Uniwersytet Ekonomiczny w Poznaniu

\title{
Działalność organizacji turystycznych w Polsce na przykładzie Darłowskiej Lokalnej Organizacji Turystycznej
}

\section{Wprowadzenie}

$\mathrm{T}$ urystyka stanowi interdyscyplinarny obszar działań. Z punktu widzenia marketingu, należy traktować ją jako sektor gospodarki tworzący nowe wartości użytkowe (usługi) oraz formę aktywności ludzkiej generującą popyt na te usługi. Na sektor turystyczny składają się przedsiębiorcy turystyczni oraz obszary turystyczne, tzw. miejsca docelowe, zwane destynacjami, na których działają jednostki samorządu terytorialnego oraz organizacje turystyczne. Sektor turystyczny musi komunikować się ze swoimi nabywcami oraz całym społeczeństwem, aby przekonać, iż może lepiej i taniej zaspokajać ich potrzeby niż zrobią to konkurenci.

Turystyka to również jedna $\mathrm{z}$ najdynamiczniej rozwijających się dziedzin gospodarki w ostatnich dekadach. By jednak dalej dynamicznie się rozwijała, potrzebuje inicjatyw i współpracy wielu sektorów. W wielu państwach europejskich znaczący składnik PKB generowany jest właśnie przez branżę turystyczną, co jest odpowiednio uwidocznione $\mathrm{w}$ traktowaniu turystyki na poziomie rządowym. W Polsce turystka często ewoluowała w strukturach administracji rządowej, będąc w Ministerstwie Transportu i Gospodarki Morskiej, Ministerstwie Gospodarki (rok 2000), następnie w 2003 przeniesiono ją do Ministerstwa Gospodarki, Pracy i Polityki Społecznej, w 2004 do Ministerstwa Gospodarki i Pracy, by w 2005 znalazła się chyba w najwłaściwszym resorcie, Ministerstwie Gospodarki. Jednak na krótko, bo już w 2007 roku utworzono Ministerstwo Sportu i Turystyki, które do chwili obecnej 
jest organem właściwym ds. turystyki. Resort ten często określany jest mianem „Ministerstwo Sportu”, co w istocie oddaje rzeczywistość. Turystyka, mimo że generuje olbrzymie zyski dla gospodarki krajowej, w tym resorcie zdominowana jest przez sport. Nie ujmując jego znaczenia, jest on dziedziną chłonącą środki budżetowe, a nie powiększająca dochody. Mimo to wyodrębnienie turystyki, jako działu administracji, było ważnym przejawem docenienia jej roli i znaczenia w gospodarce. Najważniejsze jednak znaczenie miały zmiany w organizacji i zarządzaniu turystyką jakie nastąpiły w latach 1999-2000: likwidacja Urzędu Kultury Fizycznej i Turystyki oraz utworzenie Polskiej Organizacji Turystycznej.

W wyniku powyższych zmian powstał trójstopniowy podział organizacyjny turystyki, co reguluje Ustawa o Polskiej Organizacji Turystycznej. Zmiany te nie stanowią o wyjątkowości Polski, ponieważ w krajach UE takie regulacje już istniały wcześniej, by w demokratyczny sposób realizować skomplikowane i różnorodne zadania wynikające z rozwoju turystyki. Doświadczenia tych państw pokazują że właśnie najbardziej efektywnym systemem organizacyjnym turystyki, zwłaszcza w sferze promocji, jest układ oparty na współdziałaniu narodowych z regionalnymi oraz lokalnymi organizacjami turystycznymi, gdzie te ostatnie są filarami tego systemu.

Jednym z ważnych zapisów ustawy o Polskiej Organizacji Turystycznej wpisanych do zadań narodowej organizacji turystycznej jest inspirowanie do tworzenia Regionalnych oraz Lokalnych Organizacji Turystycznych. Usytuowane na najniższym szczeblu struktury organizacyjnej, Lokalne Organizacje Turystyczne spełniają bardzo ważną rolę w kreowaniu produktu turystycznego, promocji turystyki regionów, jak również partnerstwa na rzecz turystyki. Jednak to dopiero w ostatnich kilku latach dostrzega się ich znaczenie.

Autor referatu podejmuje próbę oceny, czy uregulowania ustawowe odnośnie do struktury organizacyjnej turystyki w Polsce, są akceptowalne i funkcjonalne na rynku lokalnym i regionalnym. Dokonuje tego w oparciu o wiedzę teoretyczną, ale również o wiedzę empiryczną.

Ustawodawca ustanawiając przedmiotową ustawe, miał na celu stworzenie sprawnie działającego, podobnego do funkcjonujących w państwach UE, systemu. Problem w tym, że Polskiej Organizacji Turystycznej dano jednoznaczną konstrukcję prawną i organizacyjną oraz zagwarantowano środki budżetowe na realizację zadań. Regionalnym i lokalnym organizacjom turystycznym pozostawiono zaś dowolność zarówno pod względem formuły prawnej, organizacyjnej jak i zasad finansowania ich działań. Nowelizacja Ustawy wskazuje wprawdzie na przepisy Ustawy 
z dnia 7 kwietnia 1989 r. Prawo o stowarzyszeniach, które powinny mieć zastosowanie przy tworzeniu regionalnych i lokalnych organizacji turystycznych, jednak nie mają one charakteru obligatoryjnego. W praktyce więc, organizacje te jako osoby prawne działają w oparciu o dwie ustawy, Ustawę z dnia 7 kwietnia 1989 r. Prawo o stowarzyszeniach oraz Ustawę z dnia 25 czerwca 1999 r. o Polskiej Organizacji Turystycznej.

\section{Polska Organizacja Turystyczna (POT)}

Polska Organizacja Turystyczna, jako wyspecjalizowana instytucja państwowa, ma na celu promocję Polski za granicą oraz współpracę z samorządem terytorialnym i branżą turystyczną. Inicjuje ona szereg działań sprzyjających rozwojowi turystyki na terenie Polski. Przyczynia się to do komplementarnego zrozumienia turystyki przez samą branżę oraz władze samorządowe.

\section{Regionalne Organizacje Turystyczne (ROT)}

Regionalne Organizacje Turystyczne to płaszczyzna współpracy jednostek samorządu terytorialnego szczebla wojewódzkiego, organizacji branżowych oraz podmiotów gospodarczych działających w turystyce. Organizacje te tworzy się $\mathrm{w}$ celu zapewnienia profesjonalnej promocji turystyki regionu. Zadaniem regionalnej organizacji turystycznej jest:

- koordynowanie działań promocyjnych w województwie,

- promocja walorów turystycznych w kraju i za granica,

- tworzenie regionalnego systemu informacji turystycznej,

- stymulowanie tworzenia i rozwoju produktów turystycznych w regionie,

- inspirowanie i tworzenie lokalnych organizacji turystycznych,

- doskonalenie kadr dla turystyki,

- prowadzenie analiz oraz badań $\mathrm{w}$ dziedzinie turystyki w regionie.

\section{Lokalne Organizacje Turystyczne (LOT)}

Lokalne Organizacje Turystyczne są organizacjami współpracy samorządu terytorialnego (zwłaszcza samorządu szczebla powiatowego i gminnego) oraz lokalnej branży turystycznej (szeroko rozumianej ze względu na heterogeniczny charakter gospodarki turystycznej). Zakresem ich działania jest promocja tury- 
styczna obszaru obejmującego działalność tej organizacji, a w szczególności kreowania, tworzenia i promocji produktów turystycznych.

Do ważnych zadań lokalnych organizacji turystycznych należą również integracja społeczności lokalnej, gromadzenie i aktualizacja informacji o atrakcjach i produktach turystycznych oraz utrzymanie i prowadzenie lokalnych punktów informacji turystycznej.

Lokalne organizacje w większym stopniu jak regionalne wpływają na kreowanie polityki turystycznej. Tworzą przede wszystkim platformę do współpracy dla podmiotów działających w branży turystycznej i samorządów. To właśnie na samorządach szczególnie spoczywa inicjatywa tworzenia ich czy wspieranie już działających organizacji. Sprawnie działające LOT-y mogą bardzo mocno, na zasadach synergii, stymulować rozwój turystyki w regionie.

\subsection{Darłowska Lokalna Organizacja Turystyczna w Dorzeczu Wieprzy Grabowej i Unieści (DARLOT)}

Darłowska Lokalna Organizacja Turystyczna w Dorzeczu Wieprzy, Grabowej i Unieści to organizacja zrzeszająca powiat sławieński, miasto Darłowo, Sławno, gminy Sławno, Darłowo, Malechowo, Postomino, obszar Miasta i Gminy Polanów i Sianów, leżących na terenie powiatu koszalińskiego oraz przedsiębiorstwa z branży turystycznej, a także turystyczne organizacje pozarządowe. Uznanymi i rozpoznawalnymi w kraju kurortami leżącymi na terenie działania organizacji są Darłowo, Jarosławiec, Dąbki - najmłodsze polskie uzdrowisko. Wiele jest też innych, atrakcyjnych miejscowości turystycznych. Czyste powietrze, liczne lasy, rzeki i jeziora pozwalają na wypoczynek w bardzo różnej formie. Bazę turystyczną stanowi szeroka gama obiektów turystycznych. Począwszy od hoteli wysokiej klasy przez ośrodki wczasowe, kolonijne, sanatoria, parki wodne, parki rozrywki ruchowej i intelektualnej na gospodarstwach agroturystycznych i edukacyjnych kończąc. W regionie znajduje się także bardzo dużo cennych zabytków i ciekawych obiektów historycznych.

Według najnowszych danych Głównego Urzędu Statystycznego za rok 2013, powiat sławieński, w całości objęty działaniem organizacji, znalazł się na dziesiątym miejscu w kraju pod względem udzielonych noclegów. Wśród powiatów położonych nad morzem zajmuje on miejsce czwarte.

W klasyfikacji ogólnej, do której wliczane są takie miasta jak Warszawa, Kraków czy Gdańsk, powiat sławieński zajmuje piętnaste miejsce w Polsce wśród 
trzystu osiemdziesięciu powiatów. Turystyka stanowi tu jedną z najważniejszych dziedzin gospodarki.

Darłowska Lokalna Organizacja Turystyczna formalnie powstała w 2012 ro$\mathrm{ku}$, jednakże działania zmierzające do jej utworzenia czynione były już dużo wcześniej. Największą aktywność przejawiał w tych działaniach burmistrz największego ośrodka recepcji turystycznej, Darłowa. Wcześniej proponowana nazwa organizacji to: „Bałtycka Siódemka” nawiązująca do siedmiu gmin, jakie wstepnie miały ją tworzyć. Finalnie to starosta sławieński przejął inicjatywę tworzenia organizacji, biorąc za bazę teren jednostki samorządowej, którą zarządzał, powiększając ją o gminy sąsiednie w istocie należące również do tej administracji powiatowej w latach przed i zaraz po drugiej wojnie światowej. Z czasem, kiedy już uzyskano wsteppną akceptację utworzenia organizacji wszystkich jednostek samorządowych, zaproszono do grupy inicjatywnej kilku największych przedsiębiorców branży turystycznej oraz organizacji pozarządowych zrzeszających podmioty turystyczne. Grupa inicjatywna stworzyła komitet założycielski i w sierpniu 2012 roku dokonała rejestracji Darłowskiej Lokalnej Organizacji Turystycznej w Dorzeczu Wieprzy Grabowej i Unieści. Nazwa nie przypadkowo nawiązuje do Darłowa, ponieważ to Darłowo jest stolicą turystyczną regionu, a uznano, że nazwa ma być jasna i czytelna. Uznano też zgodnie, że Darłowo będzie „lokomotywą" nowo powstałej organizacji.

Konstrukcja organów stowarzyszenia, bo zgodnie ze wskazaniami ustawowymi, organizacja otrzymała formę prawną stowarzyszenia, zabezpiecza interesy wszystkich sektorów ją tworzących. Przewagę liczebną w trzynastoosobowym zarządzie stanowią przedstawiciele samorządów ( 9 osób), pozostali to przedstawiciele przedsiębiorców branżowych (2 osoby) oraz organizacji pozarządowych (2 osoby). Komisja Rewizyjna nie posiada zapisów parytetowych i nie zasiada w niej żadna osoba reprezentująca JST. Można odnieść wrażenie, że nie zachowano proporcji sektorów i powstała hegemonia grupy samorządowej, jednak założeniem tego była chęć zagwarantowania trwałości projektu oraz dbałość o środki budżetowe samorządów. Argumentacją tego stanu rzeczy były również wcześniejsze doświadczenia, kiedy to została powołana inna organizacja turystyczna (Bałtycka Organizacja Turystyczna), której statut nie posiadał podobnej konstrukcji parytetowej. Przestała ona być aktywna po pół roku działalności, a samorząd niemający swojej odpowiedniej reprezentacji do chwili obecnej nie jest w stanie zainicjować jej likwidacji, mimo że mija dziesięć lat od jej powstania i organizacja nie funkcjonuje. 
W chwili powstania Darłowskiej Lokalnej Organizacji Turystycznej do jej zarządu weszli wszyscy wójtowie, burmistrzowie partnerskich gmin oraz starosta sławieński jako prezes zarządu. Do wykonywania zadań powołano biuro oraz jego dyrektora. Sytuacja nie trwała jednak długo, bo tylko kilka miesięcy - do czasu, kiedy to przeanalizowano plany budżetowe organizacji na kolejny rok. Jasno z nich wynikało, że środki pochodzące ze składek będą niewystarczające na funkcjonowanie organizacji i realizację zakładanych celów. Organy stanęły przed decyzją o rozpoczęciu działalności gospodarczej. Nie było to jednak możliwe ponieważ blokadą była Ustawa z dnia 21 sierpnia 1997 r. o ograniczeniu prowadzenia działalności gospodarczej przez osoby pełniące funkcje publiczne (Dz.U. 1997, nr 106, poz. 679).

Z myślą o przyszłości nowo powstałej organizacji, członkowie zarządu w osobach wójtów, burmistrzów oraz starosty pojęli decyzję o wystąpieniu z niego. Ustępując, wskazali oni jednocześnie osoby, które będą ich reprezentowały. $\mathrm{Na}$ czele zarządu stanął przedstawiciel starosty sławieńskiego, wcześniej powołany dyrektor biura, pełniący jednocześnie funkcję szefa promocji powiatu w Starostwie Powiatowym. Taka konstrukcja pozwoliła Darłowskiej Lokalnej Organizacji Turystycznej podjąć działania uruchamiające działalność gospodarczą. Z perspektywy czasu okazało się, że decyzje te były słuszne, ponieważ organizacja $\mathrm{z}$ ich zastosowaniem funkcjonuje do dzisiaj, nie napotykając na większe bariery. Jest to też dobry przykład, że ustawa ta nie wpływa negatywnie na funkcjonowanie Lokalnych Organizacji Turystycznych prowadzących działalność gospodarczą.

W statucie organizacji znalazło się wiele zapisów określających jej cele i zadania. Główne to: promocja regionu w kraju i za granica, kreowanie wizerunku regionu jako atrakcyjnego turystycznie, integrowanie jednostek samorządu terytorialnego, osób, instytucji i organizacji pozarządowych oraz przedsiębiorstw zainteresowanych rozwojem turystycznym regionu, inspirowanie, pomoc w tworzeniu oraz promocja lokalnych produktów turystycznych, a także organizacja i prowadzenie systemu informacji turystycznej.

Statut organizacji określa również zakres działalności gospodarczej, jaka może być prowadzona. Wśród działań, jakie mogą być podejmowane, w jej ramach znalazły się m.in. wydawanie materiałów promocyjnych, książek, gazet, czasopism, gadżetów oraz ich dystrybucja, działalność organizatora turystyki, rekreacyjna i kulturalna, usługi przewodnickie oraz badania rynku, szkolenia, kursy oraz reklama w szerokim znaczeniu tego pojęcia. 


\section{Główne działania Darłowskiej Lokalnej Organizacji Turystycznej}

\subsection{Promocja}

Darłowska Lokalna Organizacja Turystyczna wykonuje dużą cześć działań promocyjnych w imieniu swoich członków, a prawie całość w imieniu jednostek samorządu terytorialnego. Każdego roku bierze udział w największych imprezach wystawienniczych. Wybór targów nie jest przypadkowy, ponieważ analizowane są regiony, z których przybywają na wypoczynek turyści. Nie oznacza to jednak, że nie zabiega ona o mieszkańców miast, w których obszar jej działania jest mniej popularny. W miejscowościach recepcji turystycznej obszaru działania Darłowskiej Lokalnej Organizacji Turystycznej najwięcej jest turystów z takich regionów jak Śląsk, w tym Dolny, Górny, Opolski, Mazowsze, Małopolska, Wielkopolska oraz region łódzki. To tam właśnie każdego roku kierowane są działania przypominające już znającym ten teren, by wracali, ale też zachęcające do przyjazdu nowych. Stoiska promocyjne na targach turystycznych w Katowicach, Krakowie, Wrocławiu, Opolu, Poznaniu, Łodzi czy w Warszawie, z przyjemnością odwiedzane są przez turystów tam zamieszkujących. Walory regionu i jego ofertę turystyczną prezentuje się również od chwili powstania organizacji na innych imprezach, np. podczas Jarmarku Kaziukowego w Poznaniu czy polskich obchodach Światowego Dnia Ziemi na Polu Mokotowskim w Warszawie. Akcentowany jest ekologiczny charakter regionu, wolnego od wielkiego przemysłu, o czystym środowisku naturalnym. Należy podkreślić, że region objęty jest w dużej części obszarem Natura 2000.

Akweny wodne, jakie tutaj się znajdują - rzeki Wieprza, Grabowa, Uniesta, jeziora przybrzeżne oraz basen Morza Bałtyckiego powodują, że jest to mekka dla wędkarzy. Koło terenowe Polskiego Związku Wędkarskiego jest również członkiem organizacji. Z wyżej wymienionych względów turystyka wędkarska stanowi ważny aspekt dla władz organizacji i dlatego każdego roku bierze ona udział w największej imprezie branżowej, jaką są targi „Rybomania" w Poznaniu. Ponad to, jako pierwsza w kraju Lokalna Organizacja Turystyczna uhonorowana została przez najważniejsze czasopismo branżowe „Wiadomości Wędkarskie” odznaką „Z nami na ryby”.

Dla przedmiotowej organizacji targi są ważnym elementem promocji. Co prawda nie są to już te imprezy, na których zawiera się umowy, niemniej jednak pełnią nawet ważniejszą rolę, a mianowicie stanowią olbrzymią platformę 
do kontaktów z potencjalnymi turystami. Właśnie tam wyspecjalizowana kadra dokonuje niezliczonych rozmów, zachęcając do wypoczynku. Mimo że w dobie internetu uważa się nagminnie, że targi to przeżytek, zdaniem osób decyzyjnych tej przykładowej organizacji, przeżytkiem nie są, a pełnią jedynie inną rolę. Łączą nowoczesne technologie z tradycyjnym sposobem komunikacji, do którego duża część turystów jest przyzwyczajona, nawet jeśli nowe rozwiązania techniczne są w ich użytkowaniu. Badania, jakie prowadzone są wśród turystów odwiedzających Centra Obsługi Turystycznej, pod nadzorem Katedry Turystyki Akademii Morskiej w Gdyni, wskazują targi jako jeden z ważnych czynników wyboru miejsca wypoczynku przez turystów. Targi to również miejsce na swoisty event, podczas którego w sposób zaplanowany przekazuje się informacje o regionie i ofercie turystycznej. Darłowska Lokalna Organizacja Turystyczna w maju 2015 roku będzie regionem wiodącym targów turystycznych „W Stronę Słońca” w Opolu. Mieszkańcy Śląska Opolskiego to pożądany target, dlatego też podczas kilkudniowej prezentacji zaprezentowany zostanie dorobek kulturalny oraz bardzo urozmaicona oferta turystyczna. W roku 2016 planowany jest podobny event, który zorganizowany zostanie na targach „Na styku kultur” w Łodzi.

Z przeznaczeniem na targi i imprezy zewnętrzne przygotowywane są materiały promocyjne. W 2014 roku opracowano i wydano dwukrotnie foldery o regionie, o produktach turystycznych $\mathrm{z}$ ukierunkowaniem na konkretnego turystę np. „Darlot z dzieckiem”, „Darlot z historią”, czy „Z Darlotem po zdrowie i urodę" (dziesięć ofert tematycznych). Wydane zostały również mapy z zaznaczeniem szlaków i ścieżek rowerowych. Liczba wszystkich wydawnictw to kilkadziesiąt tysięcy sztuk, a cześć z nich opracowano w języku polskim i niemieckim.

\subsection{Informacja turystyczna}

Informacja turystyczna to niezbędny składnik promocji turystycznej, ma ona służyć nie tylko turystom, ale również organizatorom wypoczynku grupowego i innych różnorodnych form turystyki. Z informacji turystycznej korzystają biura podróży, organizacje społeczne i animatorzy wypoczynku. System „it” uczestniczy w upowszechnianiu turystycznego modelu zagospodarowania wolnego czasu. 
Darłowska Lokalna Organizacja Turystyczna prowadzi trzy całoroczne Centra Obsługi Turystycznej. W tym roku planuje uruchomić sześć punktów „it” sezonowych w mniejszych miejscowościach turystycznych. Nowatorskim sposobem jest nawiązanie współpracy z właścicielami miejscowych sklepów. To tam zostaną zlokalizowane regały z materiałami promocyjnymi o regionie, jego atrakcjach oraz bazie turystycznej. Przeprowadzone zostanie także szkolenie osób, które będą udzielały informacji turystom. Punkty zostaną specjalnie oznakowane.

Centra Obsługi Turystycznej oferują standardowo sprzedaż pamiątek, map, rozmaitych periodyków o regionie, ale również prowadzą sprzedaż biletów na rejsy na duńską wyspę Bornholm. Prowadzona jest też sprzedaż biletów autokarowych na całą Europę, biletów do Warszawy w sezonie letnim oraz biletów na wszelkie wydarzenia kulturalne, mecze, spektakle, koncerty w kraju, co stanowi bardzo dobrą ofertę dla mieszkańców.

Poza tym centra posiadają również wydzielone pomieszczenia stanowiące pracownie reklamowe, które wyposażone są w odpowiedni sprzęt i maszyny, gdzie przygotowuje się i wykonuje projekty na swoje potrzeby, ale także na zamówienia przedsiębiorstw turystycznych, samorządów czy mieszkańców. Pracownicy posiadają również wiedzę i możliwości do oprowadzania wycieczek po terenie.

Inne podejście do „it”, otwarcie się również dla mieszkańców sprawiło, że działania organizacji turystycznej stały się znane w regionie, a tym samym bliskie jego mieszkańcom, nawet tym, którzy nie prowadzą działalności turystycznej. To bardzo ważny aspekt w działalności samej organizacji.

\subsection{Inicjatywy ponadlokalne}

Darłowska Lokalna Organizacja Turystyczna podejmuje szereg inny działań, które niekoniecznie natychmiast można uznać za działania promocyjne, ale które na pewno przyczyniają się do promocji regionu. Debata „Media a Turystyka" to najważniejsze z nich. Przedsięwzięcie ma na celu podejmowanie dyskusji na temat wpływu mediów na rozwój turystyki. Zorganizowano już trzy edycje debaty, a jej echa słyszalne są w całym kraju. To za sprawą samych uczestników, ale także ogólnopolskich mediów branżowych opisujących tę inicjatywę jako słuszną i potrzebną. Oceniana jest też jako jedyna taka dyskusja w kraju, a na pewno jedyna organizowana przez lokalną organizację tury- 
styczną. Debata rozrasta się, a widać to chociażby po instytucjach patronujacych trzeciej edycji. Została objęta patronatem prezesa Polskiej Organizacji Turystycznej, Zachodniopomorskiej Regionalnej Organizacji Turystycznej, Polskiej Federacji Turystyki Wiejskiej i patronatem naukowym rektora Akademii Morskiej w Gdyni. Uczestnikami dyskusji są przedstawiciele mediów ogólnopolskich branży turystycznej, nauki, organizacji i przedsiębiorców turystycznych. Począwszy od przyszłej edycji, debata posłuży również jako miejsce do dyskusji na temat wspólnej promocji całego Wybrzeża, a do inicjatywy włączą się Pomorska i Zachodniopomorska Regionalna Organizacja Turystyczna.

Kolejną inicjatywą Darłowskiej Lokalnej Organizacji Turystycznej jest „Regionalbus”, wycieczki po regionie dla jego mieszkańców. Przedsięwzięcie finansowane jest ze środków pozyskiwanych z budżetu powiatu sławieńskiego oraz własnych, w myśl przysłowia „Swego nie znacie...”. Wycieczka organizowana jest dwa razy do roku wiosna i jesienią. Dwa autokary wycieczkowiczów pod kierownictwem wyspecjalizowanych przewodników, pracowników Darlotu wyruszają w trasy, odwiedzając najciekawsze miejsca regionu. Sa to atrakcje turystyczne odwiedzane przez turystów wypoczywających na tym terenie, a niekoniecznie będące punktem zainteresowania mieszkańców W jej trakcie organizowany jest posiłek, najczęściej również w ciekawym miejscu, przystań kajakowa, żeglarska. Na koniec dnia, po dziesięciu godzinach autokary zjeżdżają się w jednym miejscu na zakończenie. Dzisiaj impreza jest rozpoznawalna i oczekiwana, a w ciagu trzech ostatnich lat zorganizowano dziewięć jej edycji.

\subsection{Szkolenia}

Kolejną bardzo ważną inicjatywą są szkolenia dla branży turystycznej. W roku 2014 zorganizowano szkolenie „Profesjonalizm w obsłudze ruchu turystycznego", w którym wzięło udział ponad trzydzieści osób. Szkolenie przeprowadziła wysoko wyspecjalizowana kadra z zachodniopomorskiego Uniwersytetu Technologicznego w Szczecinie, Akademii Morskiej w Gdyni, Polskiej Organizacji Turystycznej oraz Zachodniopomorskiej Regionalnej Organizacji Turystycznej. Wysokiej jakości usługi świadczone w turystyce to podstawa na równi z jakością techniczną obiektów. Specjaliści oceniają, że nawet ważniejsza, ponieważ zdarza się, że obiekt turystyczny posiada pewne niedomagania techniczne, ale ma profesjonalna, miłą obsługę. Wtedy usterki techniczne schodzą na drugi plan, zadowolony turysta i tak wróci. W odwrotnym przypadku przy tak 
dużej ilości dobrych technicznie obiektów, turysta może wybrać obiekt konkurencyjny. Planowane są kolejne szkolenia kierowane do branży turystycznej.

\section{Współpraca transgraniczna}

Nie tylko współpraca na terenie kraju jest objęta działaniami Darłowskiej Lokalnej Organizacji Turystycznej. Razem z Zachodniopomorską Regionalną Organizacją Turystyczną i Starostwem Powiatowym w Sławnie promuje ona region również poza granicami kraju. Berlin i dwudniowa impreza zorganizowana z okazji Dnia Dziecka na jednym z większych placów Alexander Platz, to miejsce, gdzie od dwóch lat organizacje wspólnie zachęcają mieszkańców niemieckiej stolicy do wypoczynku nad polskim morzem. Kolejną inicjatywą jest podjęcie partnerskiej współpracy z organizacją turystyczną działającą w regionie i kraju o zupełnie innej specyfice niż Polska. To Severný Spiš Pieniny ze Słowacji. Współpraca ta pokazuje, że wiele zależy od ludzi działających w tych organizacjach. Jednej i drugiej stronie zależy na promocji swoich regionów, czyli mają zbieżne cele. Mimo że to inne regiony, inne struktury organizacyjne turystyki w obu krajach, to współpraca jest bardzo pomocna w wymianie doświadczeń i informacji. Cenne są też same działania promocyjne zapoczątkowane przez obie organizacje. W ramach współpracy partnerskiej przekazywane są wzajemnie materiały promocyjne obu regionów. Bez dodatkowych kosztów informacje o możliwościach wypoczynku nad polskim morzem znajdują się na Słowacji, a w Centrach Obsługi Turystycznej Darlotu można dowiedzieć się, jakie możliwości wypoczynku oferuje się za południową granicą. Bardzo cennym jest, że słowacka organizacja objęła patronatem honorowym organizowaną przez Darłowską Lokalną Organizację Turystyczną, ubiegłoroczną edycję debaty „Media a Turystyka”. Prezes tej organizacji wziął udział w konferencji, dzieląc się wiedzą na temat kształtu stosunków mediów z branżą turystyczną w jego kraju.

\section{Podsumowanie}

Nowa rzeczywistość gospodarcza kraju związana z absorbowaniem środków Unii Europejskiej, w tym także przeznaczonych na rozwój infrastruktury regionalnej, wpływa w bardzo dużym stopniu na rozwój turystyki. Powstaje wiele nowych obiektów turystycznych w regionach recepcji turystycznej, ale też już istniejące nabierają nowego, nowoczesnego kształtu, dostosowanego do 
potrzeb i oczekiwań turystów. To właśnie teraz, bardziej niż kiedykolwiek, potrzebne są spójne i wspólne działania samych obiektów oraz jednostek samorządu terytorialnego. Szczególnie działania promocyjne, które zapewnią napływ turystów, co w efekcie poprawi kondycję finansową podmiotów turystycznych i tym samym wpłynie na rozwój regionu. Łącznikiem tych wysiłków powinny być właśnie Lokalne Organizacje Turystyczne. To w tych gremiach można tworzyć politykę promocji z korzyścią dla każdego z sektorów. Dobrze zarządzana organizacja, kumulując środki, ma wiele więcej możliwości niż pojedyncze obiekty czy samorządy na podejmowanie działań promocyjnych. Mając ponadto do dyspozycji odpowiednich specjalistów, może mieć olbrzymi wpływ na rozwój turystyki danego regionu i jego rozpoznawalność w kraju i zagranicą. Wskazana jako przykład, Darłowska Lokalna Organizacja Turystyczna, mimo że jest organizacją stosunkowo młoda, potrafiła $\mathrm{w}$ profesjonalny sposób określić swoje cele i je krok po kroku realizować, podejmując działania, które z natury mogłyby wydawać się nie dla niej przeznaczone. Podejmuje współpracę z Polską Organizacją Turystyczną, z Regionalną Organizacją Turystyczna, z ministerstwami, ale także z organizacjami działającymi na terenie innych krajów. Prowadzi działalność gospodarczą, której obroty w 2014 roku przewyższyły trzykrotnie dochody ze składek członkowskich. Czy w końcu podejmuje inicjatywy dotyczące problematyki ogólnokrajowej, takie jak debata „Media a Turystyka”. Warto tutaj przytoczyć jedną z opinii, która ukazała się w ogólnopolskich mediach branżowych, opinii, która może być swoistą nagrodą dla tej organizacji, ale też stanowić bodziec do dalszego działania: „Darłowska Lokalna Organizacja Turystyczna należy niewątpliwie do grupy najbardziej kreatywnych: nie tylko mówi się tutaj o poszukiwaniu dróg, tworzenia i promowania innowacyjnych produktów turystycznych, ale te drogi się odnajduje. Wystarczy choćby spojrzeć na aktywność Darlotu na wielu targach turystycznych, wspaniale zaopatrzone i wyróżniające się wystrojem stoiska, a zwłaszcza profesjonalizm przedstawicieli. Darlot daje dobry przykład" (Piotrowski, Darlot z mediami...).

Wniosek z tego płynie taki, że Lokalne Organizacje Turystyczne są bardzo potrzebne, a jeśli są dobrze zarządzane, wykazują inicjatywę, inwencję i wolę współpracy, mogą przynieść wiele korzyści i pozytywnie wpływać na rozwój turystyki i regionu, w którym działają. Mogą też być doskonałym partnerem do współpracy przy podejmowaniu działań promocyjnych Polski, jako kraju przyjaznego turystom i dbającego o nich. 


\section{Bibliografia}

J. Borzyszkowski, Organizacja i Zarzadzanie Turystyka w Polsce, Warszawa 2011.

Darłowska Lokalna Organizacja Turystyczna, Statut, 2012.

Kodeks Dobrych Praktyk, www.pot.pl (15.12.2014 r.).

Kruczek Z., Walas B., Promocja i informacja w turystyce. Proksenia, Kraków 2010.

Migdal M., Lokalna Organizacja Turystyczna, Forum LOT, Szczecin 2014.

Piotrowski J.P., Darlot $z$ mediami za pan brat, www.aktualnościturystyczne.pl (20.12.2014).

Piotrowski J.P., Wraz z reszta unijnych krajów jesteśmy na wlaściwej drodze, www.aktualnościturystyczne.pl (20.12.2014).

Turystyka 2013, Główny Urząd Statystyczny, Rzeszów 2013.

Ustawa z dnia 21 sierpnia 1997 r. o ograniczeniu prowadzenia działalności gospodarczej przez osoby pełniące funkcje publiczne Dz.U. 1997, nr 106, poz. 679.

Ustawa z dnia 25 czerwca 1999 r o Polskiej Organizacji Turystycznej Dz.U. z 1999 nr 62, poz. 689.

Ustawa z dnia 7 kwietnia 1989 r. Prawo o stowarzyszeniach Dz. U. 1989, nr 20, poz. 104.

www.pt.pl.

\section{Activities of tourist organizations in Poland presented on the example of the Local Tourist Organization in Darlowo}

\section{Summary}

The aim of the author was to show that local tourist organizations can conduct their business activities in accordance with the existing legislation concerning the tourism industry. The article points out that nowadays Local Tourist Organizations play an importance role in the development of tourism in the regions. A review of literature and the presented case have been used to prove that the impact of this basic organizational unit of the tourist industry in Poland is much greater than it is generally believed. It is these organizations that should comprise, and more and more frequently they do, tourism businesses, local governments and other entities which are concerned about the development of tourism in their regions.

The article presents The Local Tourist Organization in Darlowo, its background, and the most important elements of its business activity. This case made it possible for the author to prove that the Local Tourist Organization, as a basic unit of the tourism structure, acting in accordance with the existing legal regulations, has a lot of possibilities to create the region's tourism policy. It may take actions that will support tourism entities in improving their financial performance, as well as those that will stimulate the development of the tourism in the area. 